\title{
Eesti avaliku teenistuse koolitusvajaduse hindamise õppetunnid Euroopa Liidu alase koolitusvajaduse uuringute põhjal
}

\author{
Viljar Veebel ${ }^{\text {a1 }}$, Liina Kulu ${ }^{\mathrm{b}}$, Ulrika Hurt ${ }^{\mathrm{c}}$ \\ ${ }^{a}$ Kaitseväe Ühendatud Õppeasutuste sõjaväepedagoogika ja juhtimise õppetool \\ ${ }^{b}$ Eesti Panga rahapoliitika ja majandusuuringute osakond \\ c Tallinna Tehnikaülikooli logistikainstituut
}

\begin{abstract}
Annotatsioon
Artiklis analüüsitakse Eesti avaliku sektori töötajate koolitusvajaduse hindamisega seotud metodoloogilisi sõlmküsimusi, tuginedes aastatel 2002-2013 ametnike ja poliitikute seas korraldatud Euroopa Liidu alase koolitusvajaduse uuringutele. Sarnaste uuringute kaudu koolitusvajaduse kindlaksmääramisel on keskse tähtsusega kolm aspekti. Esiteks, uuring peaks olema keskendunud just koolitusvajaduse, mitte aga igapäevatöös oluliste teemade, koolitussoovide vms väljaselgitamisele. Teiseks, uuringut ette valmistavas faasis tuleb välistada tulemuste kalibreerimine, kus vastajaid suunatakse nn ohtlikele küsimustele vastama uuringu tellija jaoks sobival viisil. Kolmandaks on soovitatav peale küsitluspõhise uurimismeetodi kasutada ka mõõdetavat teadmiste kontrolli vormi (nt testi), mis võimaldab objektiivselt tuvastada vastaja kalduvust teadmisi ja oskusi üle- või alahinnata (nn DunningiKrugeri efekt).
\end{abstract}

Võtmesõnad: koolitus, avalik sektor, metodoloogia, Dunningi-Krugeri efekt

\section{Sissejuhatus: teema olulisus ja analüüsi eesmärgid}

Avaliku sektori ametnike oskustele ja teadmistele pandud ootused ning ülesanded on viimase 50-60 aasta jooksul oluliselt muutunud. Tänapäeva riigiteenistujad ei ole oma olemuselt enam pelgalt süsteemi administraatorid, vaid pigem poliitikakujundajad, kellelt eeldatakse lisaks teemavaldkonna heale tundmisele oskust hoomata oma tegevusega kaasnevaid mõjusid, vahetada infot, juhtida läbirääkimisi, mõjutada partnereid jms.

1 Sõjaväepedagoogika ja juhtimise õppetool, Kaitseväe Ühendatud Õppeasutused, Riia 12, 51013 Tartu; viljar.veebel@gmail.com 
Riikide koostöö tihenemise tulemusena ei piirdu ametnike tööpõld üksnes riigisiseste küsimuste lahendamisega, vaid tegeleda tuleb ka riiklike huvide esindamisega rahvusvahelisel tasandil. Näiteks tugineb Eesti riiklike huvide esindamine Euroopa Liidus (EL) ametnikele, kes töötavad siinsetes ministeeriumites ja Eesti Vabariigi alalises esinduses Euroopa Liidu juures. Nemad teevad Euroopa Liidu Nõukogu töörühmades enne vastava valdkonna ministrite kohtumisi ära eelnõusid puudutavad ettevalmistused, peavad sisulisi läbirääkimisi ning sõlmivad sisulised ja vormilised kokkulepped. Seega on võimeka ametnikkonna kujundamine ja järelkasvu koolitamine riigi jaoks oma huvide rahvusvahelisel esindamisel võtmetähtsusega. Eesti eelseisev Euroopa Liidu eesistumine 2018. aasta esimesel poolaastal tähtsustab ametnike koolituse teemat veelgi, kuivõrd Euroopa Liidu Nõukogu eesistujariigil on keskne roll seadusloome sujuval korraldamisel, läbirääkimiste ja protsesside juhtimisel ning avalikkuse ja meediaga suhtlemisel (Vabariigi Valitsus, 2014).

Tööks vajalike teadmiste ja oskuste kujundamise aluseks on ametnike koolitusvajaduse hindamine, mis mõjutab koolituse ülejäänud etappe, s.o koolituse planeerimist, läbiviimist, arvestust, aruandlust ja hindamist. Koolitusvajaduse väljaselgitamine avalikus sektoris peaks koolitusvajaduse kindlaksmääramise üldise loogika kohaselt lähtuma valdkonna, organisatsiooni ja ametipositsioonide/indiviididega seonduva hetkeolukorra ja tulevikus soovitava olukorra ning nendevahelise lõhe väljaselgitamisest. Peale organisatsiooni ootuste tuvastamise tuleb avaliku sektori puhul ka välja selgitada, milliseid teadmisi ja oskusi eeldab riik ametnikelt, ning hinnata, millised vajadused on kesksed võrreldes teadmiste tegeliku puudujäägiga. Lähtudes asjaolust, et liikmesriike esindavate ametnike koolitamine on iga Euroopa Liidu liikmesriigi enda ülesanne, on ka ametnike koolitusvajaduse väljaselgitamisel jäetud liikmesriikidele vabad käed. Eestis vastutab avaliku teenistuse üldise arendamise, värbamise ja juhtimise eest Rahandusministeerium, ametnike Euroopa Liidu alast keskset koolitust korraldab Riigikantselei. Samas on igal ministeeriumil õigus ise kujundada oma personalipoliitikat ja otsustada, kuidas ta oma ametnikke arendab, koolitab ja motiveerib ning milliseid väärtusi esile tõstab.

Eeskätt personalijuhtimise detsentraliseerituse tõttu on Eestis siinse ametnikkonna Euroopa Liidu alaste koolituste planeerimisel puudunud järjepidevus. Ehkki ametnike Euroopa Liidu alane koolitusvajadus oli tähelepanu all juba 1997. aastal, mil kiideti heaks Eesti riigiametnike Euroopa Liidu alase koolituse esimene strateegia ${ }^{2}$, hakati selle küsimusega süsteemselt

1997. aastal valminud strateegias määrati kindlaks koolituse peamised sihtrühmad avalikus teenistuses, koolitussuunad ja -meetodid ning ametnike Euroopa Liidu alase koolituse üldiseks koordineerijaks määrati Riigikantselei eurointegratsiooni büroo. 
tegelema 2002. aastal, mil koolituste korraldamisele suunatud ESKO Koolitus ja Konsultatsioonid viis läbi esimese Euroopa Liidu alase koolitusvajaduse uuringu ning valmis põhjalikum koolitusstrateegia ajavahemikuks 2002-2005. Järgmise uuringu tegi 2008. aastal akadeemilise taustaga Tartu Ülikooli Euroopa kolledž. Viimase samasisulise uuringu viis 2013. aastal läbi uurimiskeskus PRAXIS. Kõik kolm aastatel 2002-2013 tehtud uuringut tellis Riigikantselei ning igas uuringus kasutati varasemast mõneti erinevat metoodikat ja valimit. Siinses artiklis analüüsitakse ja võrreldakse eelnimetatud kolmes uuringus Eesti ametnike Euroopa Liidu alase koolitusvajaduse hindamiseks kasutatud mudeleid ning osutatakse koolitusvajaduse väljaselgitamisel esilekerkivatele peamistele ohtudele. Analüüsi tulemusena antakse metodoloogilisi soovitusi sarnaste uuringute korraldamiseks tulevikus. Uurimuses analüüsitakse üksnes koolitusvajaduse hindamisega seonduvat, jättes vaatluse alt välja muud koolitustsükli etapid (s.t koolituse planeerimine, korraldamine, arvestus, aruandlus ja hindamine).

Teoreetilise raamistiku piiritlemiseks keskendutakse Eesti uuringute analüüsil kolmele aspektile: a) millised on eelnimetatud uuringutes koolitusvajaduse hindamise üldised põhimõtted ja analüüsivahendid? b) millisele konkreetsele metoodikale tuginedes on selgitatud välja lõhe ametnike olemasolevate teadmiste ja oskuste ning tulevikuvajaduste vahel? c) kas ja kuidas on eelnimetatud uuringutes ametnike koolitusvajadusi analüüsitud individuaalselt? Teistest sama valdkonna uurimustest (Kumpikaitė \& Šiugždinienè, 2008; Meyer-Sahling, 2011; Talts \& Tuisk, 2000) eristubki praegune uurimus koolitusvajaduse hindamise metodoloogilistele, mitte korralduslikele küsimustele keskendumise poolest. Samuti jääb artikli eesmärgist tulenevalt täpsema vaatluse alt välja see, millised olid Eesti ametnikkonna Euroopa Liidu alaste teadmistega seotud konkreetsed koolitusvajadused, mis ilmnesid eelnimetatud uuringutest.

\section{Aastatel 2002-2013 korraldatud uuringute peamised karakteristikud}

Koolitusvajaduse hindamise üldiste põhimõtetega seoses määras Eestis aastatel 2002-2013 korraldatud avaliku sektori Euroopa Liidu alase koolitusvajaduse uuringute fookuse eelkõige see, millises faasis oli Eesti riigi integratsioon Euroopa Liiduga. Sellest annavad uuringute põhjal tunnistust nii järjest konkreetsemaks muutuv teemade ring, ulatuslikum valim kui ka üksikasjalikumad koolitussoovitused (vt tabelid 1 ja 2). 
Tabel 1. Eesti ametnike Euroopa Liidu alase koolitusvajaduse hindamine aastatel 2002-2013

\begin{tabular}{|c|c|c|}
\hline $\begin{array}{l}\text { Uuringu } \\
\text { korraldaja, aasta }\end{array}$ & Analüüsivahend & Uuringus käsitletavad teemad \\
\hline $\begin{array}{l}\text { ESKO Koolitus } \\
\text { ja Konsul- } \\
\text { tatsioonid, } 2002\end{array}$ & $\begin{array}{l}\text { Vastaja enesehinnang } \\
\text { ankeetintervjuu vormis. }\end{array}$ & $\begin{array}{l}\text { Uuring hõlmas hinnangut teadmistele } \\
\text { järgmistes valdkondades: üld- } \\
\text { teadmised EList (otsustusprotsess, } \\
\text { õigussüsteem, ELi programmid jm), } \\
\text { valdkondlikud teadmised (Eesti } \\
\text { osalemine ELi komiteede ja töö- } \\
\text { rühmade töös, võimalused mõjutada } \\
\text { otsuseid ELi institutsioonides, läbi- } \\
\text { rääkimised, koostöö liikmesriikidega } \\
\text { ja võõrkeeled). }\end{array}$ \\
\hline $\begin{array}{l}\text { Tartu Ülikooli } \\
\text { Euroopa kolledž, } \\
2008\end{array}$ & $\begin{array}{l}\text { Vastaja enesehinnang } \\
\text { veebipõhise ankeetküsitluse } \\
\text { vormis (fikseeritud vastuse- } \\
\text { variantidega küsimused), } \\
\text { lisaks vabatahtlik } 30 \\
\text { küsimusest koosnev ELi } \\
\text { põhiteadmiste test ning } \\
\text { kõrgemate ametnikega tehtud } \\
\text { poolstruktureeritud intervjuud } \\
\text { Eesti üldise koolitus- } \\
\text { vajaduse kohta; küsimused } \\
\text { koolitusvajaduse proport- } \\
\text { sioonide, koolitusmeetodite } \\
\text { ja koolitusvajaduse uurimise } \\
\text { ning koolitusmotivatsiooni } \\
\text { kohta. }\end{array}$ & $\begin{array}{l}\text { Uuring hõlmas hinnangut teadmistele } \\
\text { ja praktilistele oskustele } 14 \text { teema- } \\
\text { valdkonnas. Eristati teadmisi (euro- } \\
\text { integratsioon, ELi institutsioonid ja } \\
\text { otsustusprotsess, ELi õigus, liikmes- } \\
\text { riikide eripärad, otsustusprotsessis } \\
\text { osalemine ja partnerite mõjutamine, } \\
\text { Eesti huvid ELis, kommunikatsioon) } \\
\text { ja oskusi (otsustusprotsessis osale- } \\
\text { miseks vajalik taustatöö, partnerite } \\
\text { mõjutamine, kommunikatsioon, ELi } \\
\text { õiguse rakendamine ja seisukohtade } \\
\text { kujundamine). }\end{array}$ \\
\hline PRAXIS, 2013 & $\begin{array}{l}\text { Vastaja enesehinnang } \\
\text { veebipõhise ankeetküsitluse } \\
\text { vormis ning } 360^{\circ} \text { hindamisega } \\
\text { ankeetküsitluse vormis. } \\
\text { Uuringu tulemuste analüüsis } \\
\text { osales ja aitas tulemusi tõlgen- } \\
\text { dada sihtrühma esindajatest } \\
\text { ja ekspertidest koosnev } \\
\text { töörühm. }\end{array}$ & $\begin{array}{l}\text { Uuring hõlmas Eesti eesistumise } \\
\text { kompetentsimudelis esitatud } \\
\text { teemasid. Eristati teadmisi-oskusi (ELi } \\
\text { institutsioonid ja otsustusprotsess, } \\
\text { ELi kultuurikontekst, teadmised Eesti } \\
\text { riigi valitsemisest, poliitikavaldkonnal } \\
\text { põhinevad teadmised, inglise keele } \\
\text { oskus, töökogemus) ning kompe- } \\
\text { tentse (läbirääkimine ja mõjutamine, } \\
\text { kommunikatsioon ja info juhtimine, } \\
\text { koostöö, juhtimine, eestvedamine, } \\
\text { kohanemisvõime ja arenguvalmidus). }\end{array}$ \\
\hline
\end{tabular}


Tabel 2. Eesti ametnike Euroopa Liidu alase koolitusvajaduse uuringute valim ja vastamismäär

\begin{tabular}{l|l|l}
\hline $\begin{array}{l}\text { Uuringu } \\
\text { korraldaja, aasta }\end{array}$ & Valim & Vastamismäär \\
\hline $\begin{array}{l}\text { ESKO Koolitus ja } \\
\text { Konsultatsioonid, } \\
2002\end{array}$ & $\begin{array}{l}\text { Valimisse kuulus 342 ametnikku. Valim } \\
\text { koostati koostöös Riigikantseleiga } \\
\text { ning selles olid esindatud kõikide } \\
\text { ministeeriumite (v.a Välisministeeriumi) ja } \\
\text { Eesti Panga ametnikud. }\end{array}$ & $\begin{array}{l}\text { Vastamismäär oli } \\
72 \% \text {. Valimi koostas } \\
\text { Riigikantselei. }\end{array}$ \\
\hline $\begin{array}{l}\text { Tartu Ülikooli } \\
\text { Euroopa kolledž, } \\
2008\end{array}$ & $\begin{array}{l}\text { Valimisse kuulus 556 ametnikku (sh 61 } \\
\text { tippametnikku). Valimi oli ette andnud } \\
\text { Riigikantselei ning see sisaldas ELi } \\
\text { teemadega tihedalt kokku puutuvaid } \\
\text { ametnikke, nõukogu töörühmadesse } \\
\text { ja eksperdikomisjonidesse kuuluvaid } \\
\text { ametnikke, samuti Riigikogu kantselei } \\
\text { ning saatkondade ametnikke. }\end{array}$ & $\begin{array}{l}\text { Vastamismäär oli 38,7\%; } \\
126 \text { ametnikku sooritasid } \\
\text { ELi põhiteadmiste testi; } \\
\text { lisaks tehti 15 intervjuud } \\
\text { ja vahetati mõtteid 25 } \\
\text { ametnikuga. }\end{array}$ \\
\hline PRAXIS, 2013 & $\begin{array}{l}\text { Valimisse kuulus 1165 ametnikku. Uuringu } \\
\text { sihtrühma moodustasid Eesti poliitikud, } \\
\text { kes juba esindasid Eestit ELi küsimustes, } \\
\text { ning lisaks ametnikud, kelle tööülesanded } \\
\text { olid seotud ELiga või kelle puhul võis } \\
\text { arvata, et nad hakkavad ELi teemadega } \\
\text { lähitulevikus tegelema. Samuti kuulusid } \\
\text { uuringu valimisse need, kes olid oma } \\
\text { varasematel töökohtadel puutunud kokku } \\
\text { ELiga seotud ülesannetega. }\end{array}$ & $\begin{array}{l}\text { Vastamismäär oli 48,1\% } \\
\text { (täielikult vastas küsi- } \\
\text { mustikule 561 inimest); } \\
360^{\circ} \text { hindamises osales } \\
20 \text { inimest, nende } \\
\text { hindajaks oli 68 inimest. } \\
\text { Valimi } \\
\text { koostas Riigikantselei. }\end{array}$ \\
\hline
\end{tabular}

Näiteks analüüsiti 2002. aastal ESKO Koolituse ja Konsultatsioonide korraldatud uuringus, millised olid ametnike Euroopa Liiduga seotud tunnetatud ja ametikohast lähtuvad tegelikud koolitusvajadused ning millised peaksid olema koolitusteemad ja mahud, et need võimaldaksid saavutada uuringu tellija poolt soovitud teadmiste taset. 2008. aastal Tartu Ülikooli Euroopa kolledži korraldatud uuring keskendus Eesti kui juba aktiivse liikmesriigi ametnike Euroopa Liidu alaste teadmiste tunnetatud ja mõõdetud tasemete ning koolitusvajaduse väljaselgitamisele ja koolituseesmärkide seadmisele järgmiseks viieks aastaks. 2013. aastal PRAXISe läbi viidud uuringus analüüsiti ametnike koolitusvajadust avaliku sektori kompetentsi mudeli alusel, et tagada tulemuslik Eesti eesistumine 2018. aastal ning kasvav võimekus rahvusvahelises koostöös.

Esimene uuring oli ankeetküsimustiku vormis (ESKO ..., 2002), teises uuringus lisandusid enda ja kolleegide teadmisi hindavale internetipõhisele 
ankeetküsitlusele Euroopa Liidu alaseid põhiteadmisi mõõtev vabatahtlik test ja poolstruktureeritud intervjuud kõrgemate ametnikega (Tartu Ülikooli ..., 2008) ning kolmandas uuringus tehti sihtrühma veebipõhisele küsitlusele lisaks $360^{\circ}$ hindamine ankeetküsitluse vormis ja tõlgendati uuringu tulemusi sihtrühma esindajatest ja ekspertidest koosnevas töörühmas avaliku sektori kompetentsimudeli raames (PRAXIS, 2013). Seega kombineeriti uuringutes analüüsivahendeid omavahel ning iga järgneva uuringuga laiendati käsitletavaid valdkondi.

Kõigi kolme uuringu valim koostati koostöös Riigikantseleiga, seega oli uuringu tellijal võimalus määrata kindlaks uuringus osalejad, kelle koolitusvajadust sooviti hinnata ja sellega ka mõneti uuringu tulemust suunata. Uuringule vastamise määr oli kõrgeim esimeses, üksnes ankeetintervjuu vormis toimunud uuringus ning mõneti väiksem uuringutes, kus kasutati lisavahendeid.

Ametnike olemasolevate Euroopa Liidu alaste teadmiste ja oskuste ning tulevikuvajaduste vahelise lõhe väljaselgitamiseks jagati 2002. aastal ESKO Koolituse ja Konsultatsioonide korraldatud uuringus koolitusteemad kolme ossa (üldkoolitus, valdkonnaspetsiifiline koolitus ja keelekoolitus) ning vastajatelt küsiti hinnangut selle kohta, kui vajalikud on nimetatud teadmised nende igapäevatöös ning milline on vastajate hinnang oma valdkondlikele teadmistele või oskustele. Vastajad andsid hinnanguid viiepalliskaalal (5 - „asendamatu”, 4 - „tähtis”, 3 - „üsna tähtis”, 2 - „ei ole eriti tähtis”, 1 - „ei ole üldse tähtis”). Koolitusvajaduse leidmiseks kõrvutati vastajate arvates kõige vajalikumate teemade koondarvud (tähis $V$ ) teadmiste kohta antud hinnangute koondarvuga (tähis $T$ ), mille leidmisel ei kasutatud tavalist keskmise arvutamise meetodit, vaid erimetoodikat. ${ }^{3}$ Koolitusvajadus $(K)$ leiti valemi $K=V-T$ kaudu, mida võib üldistatuna tõlgendada järgmiselt: mida vajalikum on teema ametnike töös ning mida madalamalt hindavad nad oma valdkondlikke teadmisi ja oskusi, seda suurem on vajadus koolituse järele ehk seda suurem on ka näitaja (ESKO ..., 2002).

Tartu Ülikooli Euroopa kolledži uuringus (2008) hinnati nii teadmisi kui ka praktilisi oskusi (kokku 14 teemavaldkonda) ning vastanutel paluti veebipõhises ankeetküsitluses hinnata enda teadmisi ja praktilisi oskusi (tähis T; skaalal 1 - „puudulik”, 2 - „nõrk”, 3 - „rahuldav”, 4 - „hea”, 5 - „väga hea”, 6 - „suurepärane”) ning enda koolitusvajadust (tähis $K V$; skaalal 1 - „ei puutu oma töös kokku”, 2 - „üldse ei vaja”, 3 - „pigem ei vaja”, 4 - „vajan

3 Näide: kui ametnikest hindavad konkreetse teema oma töös asendamatuks $40 \%$, tähtsaks $20 \%$, üsna tähtsaks $20 \%$, mitte eriti tähtsaks $15 \%$ ning mitte üldse tähtsaks $5 \%$ vastanutest, siis kujuneb vastajate arvates kõige vajalikumate koolituste koondarv vastavalt valemile $\mathrm{V}=5 * 40+4 * 20+3 * 20+2 * 15+1 * 5=275$ 
vähesel määral”, 5 - „tuleb kasuks”, 6 - „vajan kindlasti”). Vastajate koolitusvajaduse prioriteedid selgitati välja oskustele/teadmistele antud hinnangu (T) ning koolitusvajadusele (KV) antud hinnangu vahelise lõhena. Lisaks paluti vastajatel hinnata oma kolleegide koolitusvajadust ehk kasutati delikaatsete andmete (sissetulekut või annetusi, eelistusi või pahesid puudutavate andmete) kogumise meetodit, mis on sotsioloogias laialdaselt levinud ${ }^{4}$. Selline projitseerimine võimaldab saada andmeid pigem vastaja enda kui tema naabri/kolleegi vm kohta (Pazicni \& Bauer, 2014). Ankeetküsitluse kõrval tehti andmete kogumiseks vastajatele ka vabatahtlik Euroopa Liidu alaste põhiteadmiste test ning poolstruktureeritud rühmaintervjuud kõrgemate ametnikega (rühmas 1-4 ametnikku) (Tartu Ülikooli ..., 2008).

Uurimiskeskuse PRAXIS tehtud uuringus (2013) tugineti Rahandusministeeriumi ja Riigikantselei Euroopa Liidu sekretariaadi tellitud Eesti eesistumise kompetentsimudelile ${ }^{5}$, täiendati seda ning võrreldi sihtrühma kuuluvate Eesti ametnike ja poliitikute praegust kompetentsitaset neile kompetentsimudelis seatud ootustega. Uuringu vältel koostati 13 kompetentsile fookustatud veebiküsitlus, milles küsiti vastaja enesehinnangut nii eesistumise erinevate kompetentside kohta, mis on seotud enda koolitus- ja arendusvajadusega, kui ka eri sihtrühmade kompetentside üldise taseme kohta. Veebiküsitluse tulemuste valideerimiseks tehti lisaks $360^{\circ}$ hindamine, milles valiti eri sihtrühmade esindajatena välja 20 inimest, kelle puhul omakorda selekteeriti nende hindajad ja küsiti hindajatelt veebipõhiselt hinnangut konkreetse sihtrühma liikme kompetentsitaseme ja koolitusvajaduse kohta, kusjuures iga hinnatavat hindas kuni neli inimest. Uuringu tulemuste analüüsis osales ja aitas tulemusi tõlgendada sihtrühma esindajatest ja ekspertidest koosnev töörühm. Kompetentse ning teadmisi/oskusi hinnati järgmisel skaalal: 2 - „kasin”, 3 - „rahuldav”, 4 - „hea” ja 5 - „väga hea”. Kompetentside olulisuse hindamiseks kasutati skaalat „,õtmetähtsusega (ilma selleta ei saa reaalselt rolli täita)”, „oluline (omab suurt mõju rolli täitmisele, aga rolli täitmise edukust see lõpuni ei määratle)" ning „vähem oluline (kasulik mingites olukordades)" ning osakompetentsi vajaliku taseme hindamiseks skaalat „väga hea”, „hea” ja „rahuldav” (PRAXIS, 2013).

Ametnike koolitusvajaduse individuaalset hindamist kasutati teise ja kolmanda uuringu puhul, vastavalt vabatahtliku põhiteadmiste testi ja poolstruktureeritud intervjuude või $360^{\circ}$ hindamise ja ekspertide konsultat-

4 Näiteks küsitakse, kui palju eeldatavasti samal elujärjel inimesed teenivad, ning saadakse seeläbi adekvaatsem tagasiside ka vastaja enda sissetulekute kohta, mida vastaja ehk otsesõnu öelda ei tahtnud.

5 Kompetentsimudel on kättesaadav veebilingilt http://praxis.ee/fileadmin/tarmo/Projektid/ Valitsemine_ja_kodanike\%C3\%BChiskond/Lisa_1._Eesistumise_kompetentsimudel.pdf. 
sioonide vormis. Tartu Ülikooli Euroopa kolledži korraldatud uuringus tehti Euroopa Liidu valdkonnaga tegelevate kõrgemate ametnikega intervjuud, et saada uudseid ideid ja koguda infot asutusespetsiifiliste koolitusvajaduste kohta. Intervjuud viidi läbi ühe- kuni neljaliikmeliste rühmadena (olenevalt intervjueeritava institutsiooni valmisolekust ja huvist). Sama uuringu veebipõhise ankeetküsitluse lõpus oli küsimustikule vastajatel võimalus teha 30 küsimusest koosnev Euroopa Liidu põhiteadmiste test, mis keskendus Euroopa Liidu institutsioonide, ajaloolise kujunemise, peamiste poliitikavaldkondade, aktuaalsete arengusuundumuste ning Eesti positsioonide ja huvidega seonduvatele faktidele. Uuringu käigus tehtud testi tulemusi võrreldi asutuste (sh eraldi ministeeriumite) keskmiste lõikes (Tartu Ülikooli ..., 2008). PRAXISe uuringus viidi veebiküsitluse kõrval läbi ka $360^{\circ}$ hindamine, mille käigus anti 20-le uuringus osalevale ning eri sihtrühmi (töörühma juhte, teemajuhte, sisueksperte, sisukoordinaatoreid) esindavale uuringus osalejale tagasisidet. Tagasisidet andis kuni neli inimest, kes olid vastavalt nende vahetu juht, alluv, kolleeg või koostööpartner. Lisaks kaasati uuringusse Riigikantselei Euroopa Liidu eesistumise personalistrateegia töörühm, mis koosneb peamiselt ministeeriumite esindajatest.

\section{Hinnang Eesti ametnike Euroopa Liidu alasele koolitusvajadusele teoreetilise raamistiku põhjal}

Koolitusvajaduse analüüsi hindamise teooriate raames on välja pakutud nii koolitusvajaduse hindamise mudeleid, tasandeid kui ka analüüsimeetodeid, olenevalt sellest, kas infot vajatakse strateegiliste koolitusvajaduste või konkreetselt teadmiste/oskuste puudujääkide kindlaksmääramiseks. Oma piirangud seavad siinkohal organisatsiooni profiil, mastaap, eesmärgid, õigusraamistik ja ressursid (Cekada, 2010; Hannum \& Hansen, 1989, viidatud Cekada, 2010 järgi). Näiteks kui väikeettevõtte puhul on asjakohane kõikide ametnike intervjueerimine, ei pruugi see kulupõhiselt olla otstarbekas tuhande töötajaga ettevõttes. Samuti peaks arvestama, et erasektori ettevõte on oma otsustes sõltumatum kui riiklik ettevõte või avalik organisatsioon, kes peab oma personaliplaneerimises olema avatum ning vajaduse korral kasutama ka väljastpoolt tulevat eksperdihinnangut (Coetzee, 2006; Moore \& Dutton, 1978).

Organisatsiooni, indiviidi või sektori koolitusvajaduse hindamisel on tegemist omalaadse diagnoosimisega, mille käigus määratakse kindlaks nii valdkonna, organisatsiooni ja ametipositsioonide/indiviididega seonduv hetkeolukord kui ka soovitav olukord tulevikus (teadmised, oskused, võimed, eesmärgid, sisemised ja välised piirangud) ning selgitatakse välja 
nendevaheline lõhe (Miller \& Osinki, 2002; Watkins \& Kaufman, 1996). Üldjoontes püütakse koolitusvajaduse hindamisega leida vastus küsimusele, kas organisatsiooni vajadusi, eesmärke või probleeme saab lahendada asjakohase koolituse abil või mitte (Barbazette, 2006). Näiteks ei ole koolitusest abi olukorras, kus probleemid tulenevad pigem vähesest motivatsioonist, moraali puudumisest, õpiraskustest (Cekada, 2011), organisatsiooni struktuurist, piiratud ressurssidest või sellest, et tööjõudu pole piisavalt ja liiga paljud ametikohad on vakantsed (Sorenson, 2002). Otsustamaks, kas konkreetses valdkonnas tasuks panustada koolitusele või otsida võimelünga ületamiseks teisi lahendusi, tuleks Kaufmani, Watkinsi ja Leigh' (2001) hinnangul tugineda kulupõhisele käsitlusviisile ja võrrelda koolitusvajaduse üle otsustamisel koolitusega kaasnevaid kulusid nende kuludega, mis kaasneksid sellega, kui koolitusvajadust otsustatakse ignoreerida. Lähtudes sellest, et koolitus ei pruugi alati aidata kaasa organisatsiooni probleemide lahendamisele, on seega oluline, et koolitusvajaduse hindamise käigus tuvastataks nii sellised olukorrad, kus koolitusega on võimalik kõrvaldada mingid puudujäägid, kui ka juhtumid, mil koolitus konkreetses valdkonnas ei võimalda saavutada soovitud tulemust ega ole vajalik. Sarnane olukord ilmnes ka näiteks Tartu Ülikooli Euroopa kolledži uuringus (2008), kus ankeetküsitluse tulemused näitasid suurimat koolitusvajadust selliste teemade puhul nagu „seisukohtade kujundamine ja mõjude analüüs” ning „Euroopa Liidu institutsioonid ja otsustusprotsess", kuid samas poolstruktureeritud intervjuudes väljendati arvamust, et Eesti efektiivset esindamist ei piira mitte niivõrd vähesed teadmised Euroopa Liidu toimemehhanismidest või oma poliitikavaldkonnast, vaid pigem Eesti ametniku introvertsus, esinemisjulguse puudumine ja nõrk ühiskonnahariduslik taust ning vähene arusaam erinevate otsustusprotsessi faaside olulisusest (Tartu Ülikooli ..., 2008). Eelnev viitab olukorrale, kus koolitusvajaduse väljaselgitamise käigus on ankeetküsitluse põhjal selgunud küll koolitusprioriteedid, kuid teiste uurimisvahendite kasutamisel on ilmnenud, et nendele prioriteetidele keskendumine ei pruugi lahendada institutsiooni ees seisvaid probleeme.

Järgmiseks oluliseks aspektiks koolitusvajaduse hindamisel on vajadus koguda ja analüüsida koolitusvajaduse andmeid erinevate avaliku teenistuse tasandite kaupa (makro-, meso- ja mikrotasand), praegusel juhul vastavalt riigi / Euroopa Liidu tasandil, ministeeriumi/asutuse/osakonna tasandil ning ametniku / teiste asjaomaste ametnike tasandil. Makrotasandil hindamine peab olema suunatud valdkonna toimimiseks vajalikes võtmeteadmistes sisalduvate puudujääkide väljaselgitamisele ning nende puudujääkide olulisuse hindamisele (Coetzee, 2006). Kuivõrd Euroopa Liiduga seonduvaid tööülesandeid täitvate ametnike puhul on tähtis eelkõige see, et nad 
esindaksid riiklikke huve tulemuslikult, võib eeldada, et Euroopa Liidu otsustusprotsessiga seotud ametnike ja poliitikute jaoks on seega vaieldamatult võtmeteadmisteks liidu otsustusprotsessi tundmine, Euroopa Liidu otsustusprotsessis osalemise oskus ning riigi huvide/eesmärkide teadmine, mõistmine ja edukas esindamine. Kuna mesotasandil on oluline organisatsiooni ja selle üksuste sisekeskkonna ja vajaduste hindamine (Coetzee, 2006), tuleks keskenduda eeskätt organisatsiooniga seotud teemadele (nt personalipoliitika) ning otsustada, kas koolitusega saab olukorda muuta või tuleb puudujääkide kõrvaldamiseks otsida teisi vahendeid. Mesotasandi analüüs võimaldab hinnata lähiaastate vajadusi, mis on seotud töömahu suurenemise, restruktureerimise, rotatsiooni, uute töötajate värbamise, atesteerimise ja muu seesugusega (Coetzee, 2006). Euroopa Liidu alaste teadmiste arendamisel on mesotasandil keskseteks märksõnadeks koolitusjuhi/personalijuhi fookustatus ja asutuse juhtkonna selge struktureeritud lähenemine organisatsiooni huvidele. Riigi kontekstis on aga oluline erinevate ministeeriumite rakendatud lähenemisviiside võrreldavus ja personalipoliitika koordineeritus.

Mikrotasand hõlmab tööülesannete täitmiseks vajalike teadmiste ja oskuste määratlemist ning paremaks töösoorituseks vajalike tingimuste kehtestamist (Gould, Kelly, White, \& Chidgey, 2004). Näiteks kirjeldatakse selle raames ametikohtades tehtavaid tegevusi ning määratakse kindlaks soorituse edukuskriteeriumid. Avalikus sektoris on mikrotasandil fookuses ametnik indiviidina ja tema tööülesanded nii Euroopa Liidu otsustusprotsessis kui ka sektoripõhiselt, samuti tema tööülesannete seotus teiste ametnike omadega. Seega ei tohiks Euroopa Liidu teemadega seotud ametnike koolitusvajaduse hindamine piirduda üksnes nende Euroopa Liidu alastes teadmistes sisalduvate vajakajäämiste väljaselgitamisega (nii nagu tehti ESKO Koolituse ja Konsultatsioonide uuringus), vaid tuvastada tuleks ka organisatsiooni toimimist ja indiviidi tööülesannete edukat täitmist takistavad tegurid (nagu Tartu Ülikooli Euroopa kolledži ja PRAXISe uuringutes).

Eri analüüsitasandite infot aitab koondada ja sünteesida ka see, kui koolitusvajaduse hindamisse on kaasatud kõik asjassepuutuvad osapooled: sihtrühm, valdkonna võtmeisikud, koolituspakkujad ja süsteemivälised eksperdid erialaliitude näol. Kaks viimast Eestis tehtud uuringut kaasasid koolitusvajaduse hindamisse peale sihtrühma enda küll valdkonna võtmeisikud Eestist, kuid samas jäi eeskätt PRAXISe uuringus kasutamata koolituspakkujate kui koolitusvajaduse hindajate potentsiaal. Edaspidistes sarnastes uuringutes võiks kaaluda siinse ametnikkonna Euroopa Liidu alaste teadmiste ja oskuste kohta hinnangute küsimist ka teiste Euroopa Liidu liikmesriikide kolleegidelt. 
Lisaasjaoluna tuleks tulevikus sarnastes uuringutes küsida vastajatelt konkreetselt nende koolitusvajaduste, mitte aga igapäevatöös oluliste teemade, koolitussoovide vms kohta. Näiteks käsitleti ESKO Koolituse ja Konsultatsioonide 2002. aasta uuringus koolitusvajadust kui uuringus osalejate arvates kõige vajalikumate teemade ja oma teadmistele antud hinnangute vahet, ega küsitud neilt otseselt ametnike tööga seotud koolitusvajaduse kohta. Kui sama metoodikat oleks kasutatud näiteks PRAXISe 2013. aasta uuringus, oleks tõenäoliselt jäänud üks peamistest koolitusvajadustest Euroopa Liidu institutsioonide ja otsustusprotsessiga seonduv - tuvastamata, kuivõrd teadmisi Euroopa Liidu institutsioonide ja otsustusprotsessi kohta pidasid vastajad riigivalitsemisega seotud teadmiste järel suhteliselt heaks, kuid sellest hoolimata märgiti see ankeetküsitlustes ära ka kui valdkond, milles peeti kõige rohkem vajalikuks oma teadmisi arendada.

Koolituslõhe hindamisel on oluline, et uuringu koostajate ja sihtrühma ametnike arusaam terminitest oleks ühesugune. Nii võivad uuringus üldsõnaliselt pealkirjastatud koolitusteemad olla vastajate jaoks ebatäpsed või mingil põhjusel ebaolulised. Ilmekaks näiteks on siinkohal olukord, kus koolitusteema sõnastamine pealkirjana „Euroopa Liidu baasteadmised” viitab pigem sissejuhatavale koolitusele, samas kui alternatiivina kasutatav „Euroopa Liidu baasteadmiste värskenduskursus" oleks sobiv ka juba kogenud ametnikule.

Koolitusvajadusuuringute järgmisteks sõlmküsimusteks on nn suunatud vastuste andmine ning teadmiste/oskuste võimalik üle- või alahindamine (McGehee \& Thayer, 1961; Moore \& Dutton, 1978; Mosely \& Heaney, 1994). Kuna klassikalise hindamise puhul, mis üldjuhul koosneb hinnatava töötaja täidetavast ankeetküsimustikust, töötaja ülemuse täidetavast hinnangulehest ning töötaja ülemuse või organisatsiooni koolitusjuhiga tehtud intervjuust, jääb vastajatele võimalus lemmikteemade esiletõstmiseks ja oma nõrkade külgede varjamiseks, ei pruugi see meetod anda objektiivset tagasisidet töötaja tegeliku koolitusvajaduse kohta. Üheks lahenduseks on kasutada mõõdikutele tuginevat kaheosalist individuaalset hindamist, mille puhul kombineeritakse töötaja enda täidetav ankeetküsimustik ja temaga korraldatav vestlus töötaja vahetu ülemuse täidetava ankeetküsimustiku või temaga tehtava intervjuuga, millele omakorda lisatakse ankeetküsimustik, et hinnata üksuse / valdkonna / organisatsiooni kui terviku koolitusvajadust. See kombinatsioon toimib eelkõige üksuse sees ühe valdkonna töötajate koolitusvajaduse võrdlemisel ja hindamisel. Samas on ka see meetod väga subjektiivne, sest tegemist on üksnes indiviidide hinnangutega enda ja teiste koolitusvajaduste kohta, mitte teadmistes vajakajäämiste objektiivse väljaselgitamisega. Seetõttu on otstarbekas lisada küsitlevale hindamisele vahend, mis võimaldab objektiivselt (kuigi piiratud vahemikus) hinnata 
töötaja reaalseid teadmisi. Enamasti on selleks standardteadmiste test, mille tulemusi analüüsib koolitusvajaduse hindaja.

Eelkirjeldatud olukord, kus ei töötaja enda ega tema kolleegide hinnangud ei pruugi anda tegeliku koolitusvajaduse kohta objektiivset infot, seondub põhimõttelise kitsaskohaga koolitusvajaduse hindamise vahendite valikul. Nimelt sisaldab igasugune hinnang hetkeolukorrale ja tulevikus soovitavale olukorrale juba oma olemuselt määramatust (Miller \& Osinki, 2002): a) ebamäärasust selles, mis organisatsiooni arvates hakkab tulevikus juhtuma ja mis juhtub tegelikult, b) määramatust selles, milline on töötaja praegune tegelik tööpanus ja milline on temalt tulevikus oodatav panus, ning c) määramatust selles, millised on töötaja olemasolevad teadmised ja oskused ning mida peaks ta teadma/oskama tulevikus. Näiteks kui tavapäraselt palutakse töötajal ankeetküsimustikus nimetada oma tööga seonduvaid koolitusvajadusi, kiputakse tihti koolitusvajaduste asemel nimetama hoopis koolitussoove (Cekada, 2011), mis ei pruugi aga vajadustega ühtida. Selles kontekstis võib esineda ka nn Dunningi-Krugeri efekt, mille kohaselt kalduvad indiviidid iseenda teadmiste ja oskustega seotud võimekust ning samaväärseid vajadusi ebaobjektiivselt hindama (Dunning, Johnson, Ehrlinger, \& Kruger, 2003; Kruger \& Dunning, 1999). Vastajate seas on suur hulk neid, kes kipuvad enda teadmisi ja koolitusvajadust tahtmatult või tahtlikult ala- või ülehindama. Üldises plaanis on noored ja vähese töökogemusega töötajad enesekindlamad, mistõttu on ka teadmiste ja oskuste ülehindamine neile iseloomulikum. Staažikamad töötajad seevastu kalduvad oma teadmisi ja oskusi alahindama. Enesehinnangute lahknevus arvatavate ja tegelike teadmiste vahel tuleneb omalaadsest metakognitiivsest puudujäägist (nn kompetentsuse illusioon), mille kohaselt väiksemate teadmiste, oskuste ja kogemustega indiviidid ei oska oma teadmisi pädevalt hinnata, kuna nad ei tea, kui palju nad teavad (Dunning et al., 2003). Suuremate teadmiste ja kogemustega töötajad kipuvad aga oma teadmisi alahindama, kuna nad eeldavad ekslikult, et ka kõikide teiste teadmised on samal tasemel nagu neil endil (Kruger \& Dunning, 1999).

Tuginedes koolitusvajaduse kindlaksmääramisel üksnes töötaja enda või tema kolleegide hinnangutele, tuleb seega arvestada, et a) hinnatav ei pruugi olla teadlik, millisel tasemel peaksid tema teadmised tegelikult olema, b) hinnatav ei ole adekvaatse võrdlusmomendi puudumise tõttu enamasti teadlik, millisel tasemel on tema enda teadmised, ning c) olles isegi informeeritud enda teadmiste tasemest, ei pruugita samas olla piisavalt motiveeritud andma enda kohta õigeid andmeid. Eelnevast lähtudes on koolitusvajaduse väljaselgitamisel oluline analüüsida Dunningi-Krugeri efekti võimalikku avaldumist enesehinnangutes, sest see võimaldab 
järelduste ja soovituste tegemisel selle mõju arvestada ja vajaduse korral kompenseerida. Seega on küsitluspõhise uuringu võimaliku subjektiivsuse kompenseerimiseks otstarbekas kasutada paralleelselt ka kvantitatiivselt mõõdetavat teadmiste ja oskuste kontrolli vormi.

Kõik kolm Eestis korraldatud Euroopa Liidu alase koolitusvajaduse uuringut olid suures osas üles ehitatud vastajate endi hinnangule oma teadmiste ja tunnetatud koolitusvajaduse kohta. Eeldati, et just vastaja ise peaks olema kõige paremini informeeritud enda tööd takistada võivatest teadmiste puudujääkidest ning ta peaks oskama ja ka julgema enda koolitusvajaduse kohta infot anda. Vaid 2008. aastal tehtud uuringus keskenduti nn ootuspäraste ja tööalaselt mugavate või ohutute vastuste teemale põhjalikumalt. Euroopa Liidu põhiteadmiste testiga hinnati Dunningi-Krugeri efekti avaldumist, samuti toodi välja selle esinemise võimalikud põhjused. 2013. aastal PRAXISe tehtud uuringus mööndi samuti, et kuivõrd enamikul sihtrühma liikmetest puudub koolitusvajaduse hindamise kogemus, siis võib uuringus antud hinnang kompetentsile olla ebatäpne, kuid samas võimaliku üle- või alahindamise ulatust otseselt ei hinnatud. Samuti ei võimaldanud selle küsimuse kohta vajalikke teadmisi saada uuringu andmete kogumisel lisaallikana kasutatud nn $360^{\circ}$ uuring, kuivõrd tegemist oli hinnangulise meetodiga.

2008. aastal korraldatud Euroopa Liidu koolitusvajaduse uuringu põhjal kalduti Euroopa Liidu alaseid baasteadmisi pigem üle- kui alahindama, kusjuures samamoodi nagu teiste seda tüüpi uuringute puhul olid ka Eestis teadmiste ülehindajateks pigem vähem kogenud ametnikud, kes väitsid, et nad on oma valdkonnas head või väga head, ning kes kinnitasid, et ei vaja erialast täiendkoolitust. Kogenud ja sageli koolitustel käivad ametnikud seevastu soovisid pea kõikides valdkondades lisakoolitusi. Uuringu kohaselt polnud alust eeldada, et mingis konkreetses ministeeriumis hindavad ametnikud oma teadmisi läbivalt kas puudulikeks või piisavateks. Samas ilmnes, et 2008. aastal erinesid subjektiivne hinnang oma teadmistele ja objektiivsed testitulemused kõige rohkem Keskkonnaministeeriumi, Põllumajandusministeeriumi ning Haridus- ja Teadusministeeriumi ametnikel ning langesid kõige enam kokku Riigikogu ja Eesti alalise esinduse ametnikel. Kui võrrelda ametnike hinnanguid enda ja oma kolleegide teadmistele ja oskustele, siis enamik vastanuid hindas oma teadmisi ja oskusi kõrgemalt ning koolitusvajadust madalamalt kui kolleegide näitajaid, kusjuures tendents oli märgatavaim Kaitse-, Välis- ja Justiitsministeeriumi puhul.

Nn soovitud vastuste andmisel toodi Tartu Ülikooli Euroopa kolledži uuringus välja järgmised põhjused: „Ma ei saa meie ministeeriumi halba valgusesse seada, kõik ametnikud juba on eksperdid ega vaja koolitust ning 
kui mina ütlen, et tahaksin koolitust, võidakse mind üles otsida ning mu positsioon võib olla ohus, kui kinnitan, et vajan koolitust ja meie üksuse keskmine koolitussoov on kõrge, võib see pärssida ametnike edutamist või vähendada palka" (Tartu Ülikooli ..., 2008). Selliste suunatud vastuste andmine kajastab vastajate arvamust, et uuringu tellija hinnangul oleks ideaalseks tulemuseks olukord, kus ametnikud koolitusi ei vaja (ehk kõik oleksid ametialaselt piisaval tasemel), ning seega ongi justkui soovitatav vastata, et koolitust ei vajata. Sellise tendentsi üheks väljenduseks on 2013. aastal PRAXISe korraldatud uuring, mille puhul kasutati osakompetentsi vajaliku taseme hindamisel üksnes skaalat „väga hea”, „hea” ja „rahuldav”. Olukord on eriti tõenäoline siis, kui uuringu valim on koostatud uuringu tellija poolt või tellija otsesel juhendamisel, kusjuures uuringu tellijal on olemas info kõikide uuringus osalejate kohta (nt mitu inimest ja kes osalesid uuringus mingist konkreetsest ministeeriumist).

Olukorras, kus peale teadmiste kuuluvad hinnatavate kriteeriumite hulka võimed, sobivus ja valmisolek teenistusülesannete täitmiseks, on mõneti mõistetav, et ametnik ei soovi anda enda kohta adekvaatseid (sh kriitilisi) hinnanguid. Palgaootuse, edutamissoovi ja vallandamishirmu tõttu võivad ametnikud anda uuringutes oma teadmiste taseme kohta pigem kõrgemaid ja koolitusvajaduse kohta madalamaid hinnanguid, eeldades, et kui üksuse või asutuse keskmine hinne tuleb kõrge, premeeritakse kõiki. Samuti võib ametnik alateadlikult arvata, et silmapaistvate tulemuste saavutamine võib kindlamalt tagada tema edutamise, seda eriti olukordades, kus on teada, et valim ühes asutuses on väga väike või ankeete saab andmete järgi konkreetse isikuga seostada. Selline kartus esineb pigem keskmise või madalama kvalifikatsiooniga ametnikel. Ebamugavamatele küsimustele nn ootuspäraste vastuste andmist (nt baasteadmiste puudujääkide korral) aitab vältida ka tellija ja uuringu korraldaja eeltöö ametnikega juba uuringule eelnevas faasis (teadvustamine ja julgustamine).

Täpsemate ja objektiivsemate uurimistulemuste saamisel tuleb kasuks ka selgete ja mõõdetavate kriteeriumite seadmine. Oluliseks valikukohaks on näiteks see, kas skaalad on polariseeruvad ehk kas neutraalne vastus on lubatud või mitte. Tartu Ülikooli Euroopa Kolledži 2008. aasta uuring näitas, et sisukamate vastuste huvides on neutraalsete vastuste kasutamine küsitav (sageli ei soovi vastajad konkreetset hinnangut anda ning neutraalne vastusevariant annabki võimaluse seda mitte teha). Selle asemel võiks võimaldada vastajal jätta küsimusele vastamata. Teine põhimõtteline valik seondub sellega, kas kasutatavad skaalad on diskreetsed, s.t vastusevariantidega stiilis „, - ei ole üldse nõus, ... , 5 - täiesti nõus”, või pidevad (nt graafilised skaalad, kus vastaja saab tõmmata risti joonele, mille ühes otsas on 
väide „Ei ole üldse nõus” ja teises otsas väide „Täiesti nõus”). Diskreetsete skaalade kasutamisega seonduvad mitu probleemi. Näiteks ei tohiks rangelt võttes selliste hinnete kohta arvutada aritmeetilist keskmist, kuna tegu pole arvnäitajatega, vaid järjestusnäitajatega, mille puhul ei ole võimalik kindlaks määrata, kas näiteks väärtused „1” ja „2” on üksteisest sama kaugel kui väärtused „4” ja „5”. See omakorda komplitseerib usalduspiiride arvutamist, kuid valimipõhiste uuringute puhul on usalduspiir tulemuste ebakindluse hindamisel väga oluline näitaja. Samuti on oht, et osa infost läheb kaduma kategooriate piiratud arvu tõttu ning kategooriate sildistamine mõjutab vastajate valikuid. Eelnevat arvesse võttes tuleks eelistada pigem pidevat graafilist skaalat, mida saab veebipõhiste küsimustike puhul edukalt kasutada, kuna vastajale kuvatakse graafiliselt vahemik, mille ülem- ja alampiirid on tähistatud vastavalt positiivsete ja negatiivsete äärmuslike vastusevariantidega (vastavalt „ei ole nõus” ja „täiesti nõus”), ning vastaja esitab oma vastuse punktina sellel skaalal. See võimaldab anda vaadeldavale nähtusele täpsema hinnangu kui piiratud arvu kategooriaid kasutades ning teeb võimalikuks suurema arvu statistiliste meetodite rakendamise.

Eeltoodu põhjal võib välja tuua, et metodoloogilisest vaatenurgast on sarnastes koolitusvajaduse hindamise uuringutes olulised kolm aspekti. Esiteks, koolitusvajadusuuring peab olema fookustatud konkreetselt koolitusvajaduse, mitte aga koolitussoovide, üldise enesetäiendamise vms väljaselgitamisele. Teiseks, vältida tuleks uuringu tellija poolset uurimistulemuste suunamist tellijale või ka vastajale ebamugavates küsimustes. Kolmandaks, küsitluspõhise uuringu võimaliku subjektiivsuse kompenseerimiseks on otstarbekas kasutada paralleelselt ka mõõdetavat teadmiste ja oskuste kontrolli vormi.

\section{Hinnang koolitusvajaduse hindamise vahendite valikule, arvestades Eesti avaliku teenistuse eripära}

Eesti ametnikkonna Euroopa Liidu alase koolitusvajaduse hindamisel ja koolitusvajaduse analüüsivahendite valikul on otstarbekas arvesse võtta ka Eesti avaliku teenistuse eripära. Eesti avalikule sektorile on iseloomulikud mõneti killustunud lähenemine avaliku teenistuse kui terviku küsimustega tegelemisele ning suhteliselt noor ametnikkond, kellel on vähene kogemus rahvusvahelises koostöös osalemisel ja kellest suur osa on oma praegusel töökohal töötanud suhteliselt lühikest aega.

Eesti avaliku teenistuse süsteemile pandi alus 1995. aastal jõustunud ning 2013. aastal oluliselt muudetud avaliku teenistuse seadusega (Riigikogu, 2012). Avaliku teenistuse süsteemi ülesehitamine algas aga juba varem. 
See toimus kolmes etapis (Sarapuu, 2012; Tõnnisson \& Randma-Liiv, 2008, viidatud Savi \& Metsma, 2013 järgi):

1) varajane üleminekufaas aastatel 1991-1996, mil loodi juriidiline ja institutsionaalne raamistik avaliku teenistuse süsteemi ülesehitamiseks (nt piirivalve, keskpank) ning alustati administratiivsete ja struktuursete reformidega;

2) Euroopa Liiduga liitumise periood aastatel 1996-2004, mil administratiivsete reformide käigus keskenduti avaliku teenistuse pakutavate teenuste kättesaadavusele ning teenuste kvaliteedile, kuid samas ei osutunud see Drechsleri arvamuse kohaselt (Drechsler, 2004, viidatud Savi \& Metsma, 2013 järgi) keskse haldusmehhanismi puudumise tõttu edukaks ning Tõnnissoni ja Randma-Liivi (2008) arvates tõi see kaasa individuaalsete lahenduste heterogeensuse eri organisatsioonides;

3) Euroopa Liiduga liitumise järgne periood alates 2004. aastast, mil avaliku teenistuse reformide läbiviimine delegeeriti eri ministeeriumitele. Sellega kaasnesid pidevad muutused avaliku halduse süsteemis ning järjepidevuse puudumine.

Randma-Liiv (2009) toob välja järgmise: „Avaliku teenistuse kui terviku küsimustega tegelemine on olnud ebasüsteemne ning killustunud erinevate asutuste vahel. Avaliku teenistuse personalijuhtimises puuduvad selged strateegilised eesmärgid ning erinevate valdkondade (värbamine, hindamine, tasustamine, arendamine, teenistusest vabastamine) omavaheline loogika ja sidusus on puudulikud. Erinevate AT [avaliku teenistuse - autorite märkus] komponentide osas on kohati puuduseks ebaselge vastutuse jaotus erinevate institutsioonide vahel ning isegi koordineerimistegevuse ebaselged eesmärgid" (Randma-Liiv, 2009, lk 4-5). Killustatuse tõttu on Eesti avaliku sektori koolitusvajaduse hindamisel ilmnenud mitmeid probleeme, näiteks kuni uue avaliku teenistuse seaduse versiooni jõustumiseni

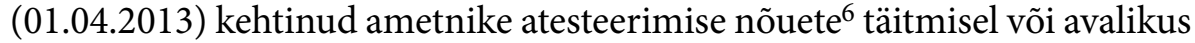
sektoris keskselt korraldatavate täiendkoolituste (sh Euroopa Liidu alaste koolituste) piiratud rahastamisel ${ }^{7}$.

6 Atesteerimine on isiku töötulemuste ja ametikohal esitatavatele nõuetele vastavuse regulaarne hindamine. Ehkki atesteerimisnõue peaks põhimõtteliselt olema meede, mis võiks olla ametnike koolitusvajaduse hindamise aluseks, kujunes praktikas sellest pigem formaalne kontrollimehhanism (vt Randma-Liiv, 2009). Just atesteerimisest kõrvalehiilimise toobki Randma-Liiv (2009) välja kui näite selle kohta, kuidas avaliku teenistuse seaduse sätetest kõrvalehiilimist peeti normaalseks ja kohati isegi tavaks.

7 Hoolimata sellest, et viimastel aastatel on toiminud ühtsetel alustel mitu avalike teenistujate arendamise programmi (keskse koolituse programm ja tippjuhtide arendamise programm), ei ole need uurimiskeskuse PRAXIS hinnangul (2013) hõlmanud ei kogu koolitustemaatikat ega sihtrühma. Keskse koolituse programmi väikse mahu tõttu sai aastatel 2008-2011 osaleda kesksetel koolitustel üksnes 5-6\% ametnikest (vt PRAXIS, 2013). 
Eesti avaliku sektori koolitusvajaduste hindamisel on esmatähtis saada võimalikult lai tervikpilt avaliku sektori institutsioonide koolitusvajadustest. Lisaks on oluline, et ühtsetel põhimõtetel ja kriteeriumitel korraldatav uuring hõlmaks võimalikult otstarbekat vastajate ringi. Vaadates Eestis aastatel 2002-2013 tehtud Euroopa Liidu alase koolitusvajaduse uuringuid, ilmneb, et valim on küll iga järgneva uuringuga suurenenud, kuid valimi osalusmäär on võrreldes esimese uuringuga langenud (vt ka tabel 2). Olukorras, kus küsitluse mingile osale (nt testile) vastamine on vabatahtlik ja anonüümne, võib juhtuda, et kas teadmatuse, huvipuuduse või vähese motivatsiooni tõttu ei pruugita saada kõrget vastamismäära (nt Tartu Ülikooli Euroopa kolledži 2008. aasta uuringu raames tehtud Euroopa Liidu põhiteadmiste testi vastamismäär oli 22,6\% koguvalimist) ja sageli ei jõua just võtmeisikud või tiheda graafikuga eksperdid küsimustikule vastata. Ühe rühma, kes jätab vastamata, moodustavad ka need, kes on oma teadmistest väga heal arvamusel või ei soovi enda kohta andmeid esitada, kartes oma teadmatuse ilmsikstulekut ja tööandja reaktsiooni. Küsimus, kuidas kaotada valimis osalejate hirme ausate vastuste andmisel, on ka siinkohal võtmetähtsusega ning seega tuleks juba enne uuringu algust jagada taustinfot uuringu olulisuse, eesmärkide ja tulemuste rakendamise kohta. Samuti tuleks vältida liiga pikki ja keerulisi ankeete, millele tuleb näiteks veebiankeedi puhul vastata ebamugavas vastamiskeskkonnas.

Seega kerkib koolitusvajaduse hindamisel Eesti ametnikkonna eripära arvestades päevakorda, kas töötaja suudab enda teadmisi, oskusi või kompetentse objektiivselt hinnata. Omaette küsimus on ka see, kui objektiivselt hindab tulevikus oma töökohal vajaminevaid teadmisi, oskusi ja kompetentse ametnik, kes on oma töökohal töötanud suhteliselt lühikest aega. Seetõttu muutub eriti tähtsaks sellise koolitusvajaduse hindamise meetodi valik, mis lubab testida Dunningi-Krugeri efekti ilmnemist ning selle ulatust.

\section{Kokkuvõte}

Avalikus sektoris toimunud paradigmamuutus valitsemiselt haldamisele on muutnud ametnike süsteemse koolitamise tähtsamaks kui kunagi varem. Valdkonna, organisatsiooni ja indiviidi hetkeolukorra ning tulevikus soovitava olukorra väljaselgitamine, arvestades eesmärke, sisemisi ja väliseid piiranguid, teadmisi, oskusi, võimeid, võimalusi jms, on hea avaliku haldaja ja teenistuja - ning seega ka hea riigi - kujundamisel üheks põhiteguriks.

Euroopa Liidu alane täiendkoolitus on riigiametnike koolituses olulisel kohal kõikides Euroopa Liidu liikmesriikides, kuivõrd just ametnikud 
on liidu tasandil need, kes tagavad rahvusriikide esindatuse ja poliitikute tahte elluviimise. Liidu viimased laienemisvoorud ning Lissaboni lepingu jõustumisega 2009. aastal rakendunud muudatused on vajadust koolituse süsteemse analüüsimise ja planeerimise järele veelgi süvendanud.

Artiklis analüüsiti ja võrreldi mudeleid, mida kasutati Eesti ametnike Euroopa Liidu alaste koolitusvajaduste hindamiseks aastatel 2002-2013 korraldatud kolmes uuringus, ning analüüsi tulemusena anti metodoloogilisi soovitusi sarnaste uuringute tegemiseks tulevikus. Uurimuses keskenduti kahele lähtekohale: 1) hinnang koolitusvajaduste uuringutele koolitusvajaduste teoreetilise raamistiku põhjal, 2) hinnang koolitusvajaduste uuringutes kasutatavate vahendite valikule, lähtudes Eesti avaliku teenistuse eripärast.

Eestis läbiviidud uuringute näitel võib riigiametnike Euroopa Liidu otsustusprotsessis osalemisega seonduva koolitusvajaduse kindlaksmääramisel välja tuua kolm olulist metodoloogilist aspekti. Esiteks, uuring peab keskenduma konkreetselt koolitusvajaduse, mitte igapäevatöös oluliste teemade, koolitussoovide vms väljaselgitamisele. Teiseks tuleb vältida suunatud vastuste andmist vastajale või tellijale ebamugavates küsimustes. Kolmandaks, uuringusse on soovitatav lisada test, vaatlus või muu teadmiste kontrolli vorm, mis võimaldab objektiivselt tuvastada vastaja teadmiste/oskuste üle- või alahindamist ehk Dunningi-Krugeri efekti. Koolitusvajaduse hindamisel ei ole seega mõistlik ega objektiivne tugineda üksnes töötaja enda või tema kolleegide hinnangutest pärinevale infole, kuivõrd seeläbi ei pruugita saada objektiivset pilti: igal koolitusvajaduse hindamise meetodil ja vahendil on oma eelised ja puudused ning neid tuleks valiku tegemisel arvesse võtta ja kompenseerida. Kui peale teadmiste kuuluvad hinnatavate kriteeriumite hulka ka töötaja võimed, sobivus ja valmisolek teenistusülesannete täitmiseks, ei pruugi ametnik soovida enda kohta adekvaatseid hinnanguid anda. Ausalt vastamine on pärsitud eeskätt siis, kui pole selge, kuidas uurimistulemusi rakendatakse, ning palgaootuse, edutamissoovi või vallandamishirmu tõttu võivad ametnikud anda uuringutes oma teadmiste taseme kohta pigem kõrgeid ja koolitusvajaduse kohta madalaid hinnanguid.

\section{Kasutatud kirjandus}

Barbazette, J. (2006). Training needs assessment: Methods, tools, and techniques. San Francisco: Pfeiffer.

Cekada, T. L. (2010). Training needs assessment: Understanding what employees need to know. Professional Safety, 55(3), 28-33.

Cekada, T. L. (2011). Need training? Conducting an effective needs assessment. Professional Safety, 56(12), 28-34. 
Coetzee, M. (2006). Empowering the skills development facilitator. Johannesburg: Knowres.

Drechsler, W. (2004). Enhancing the capacities to govern: Challenges facing the CEE countries. Selected Papers from the 11th NISPAcee Annual Conference.

Dunning, D., Johnson, K., Ehrlinger, J. E., \& Kruger, J. (2003). Why people fail to recognize their own competence. Current Directions in Psychological Science, 12(3), 83-87. doi: http://dx.doi.org/10.1111/1467-8721.01235

ESKO Koolitus ja Konsultatsioonid (2002). ELi õigusloomes Eestit esindavate ametnike koolitusnõudluse analüüs. Avaldamata käsikiri.

Gould, D., Kelly, D., White, I., \& Chidgey, J. (2004). Training needs analysis: A literature review and reappraisal. International Journal of Nursing Studies, 41(5), 471-486. doi: http://dx.doi.org/10.1016/j.ijnurstu.2003.12.003

Hannum, W., \& Hansen, C. (1989). Instructional systems development in large organizations. Englewood Cliffs: Educational Technologies Publications.

Kaufman, R., Watkins, R., \& Leigh, D. (2001). Useful educational results: Defining, prioritizing \& accomplishing. Lancaster: Proactive Publishing.

Kruger, J., \& Dunning, D. (1999). Unskilled and unaware of it: How difficulties in recognizing one's own incompetence lead to inflated self-assessments. Journal of Personality and Social Psychology, 77(6), 1121-1134. doi: http://dx.doi.org/10.1037/0022-3514.77.6.1121

Kumpikaitė, V., \& Šiugždinienė, J. (2008). Human resource development's evaluation in public management: Lithuanian case. International Journal of Business Research, (8) 4, 69.

McGehee, W., \& Thayer, P. W. (1961). Training in business and industry. New York: Wiley.

Meyer-Sahling, J.-H. (2011). The durability of EU Civil Service Policy in Central and Eastern Europe after Accession. Governance, 24(2), 231-260. doi: http://dx.doi.org/10.1111/j.1468-0491.2011.01523.x

Miller, J. A., \& Osinki, D. M. (2002). Training needs assessment. International Society for Performance Improvement. Retrieved from www.ispi.org/pdf/suggestedReading/Miller_Osinski.pdf.

Moore, M., \& Dutton, P. (1978). Training needs analysis: Review and critique. The Academy of Management Review, 3(3), 532-545. doi: http://dx.doi.org/10.2307/257543

Moseley, J. L., \& Heaney, M. J. (1994). Needs assessment across disciplines. Performance Improvement Quarterly, 7(1), 60-79.

doi: http://dx.doi.org/10.1111/j.1937-8327.1994.tb00617.x

Pazicni, S., \& Bauer, C. F. (2014). Characterizing illusions of competence in introductory chemistry students. Chemistry Education Research and Practice, 15(1), 24-34. doi: http://dx.doi.org/10.1039/C3RP00106G

PRAXIS (2013). EL otsustusprotsessiga seotud ametnike ja politikute koolitusvajaduse hindamine Euroopa Liidu nõukogu eesistumise läbiviimiseks vajalike kompetentside arendamiseks. A. Uudelepp, A. Altermann, A. Anton, J. Järvalt, J. Matt, \& R. Vinni (koost.). Külastatud aadressil http://www.praxis.ee/fileadmin/tarmo/Projektid/ Valitsemine_ja_kodanike\%C3\%BChiskond/EL_eesistumise_koolitusvajaduse_ uuringu_raport.pdf. 
Randma-Liiv, T. (2009). Avaliku teenistuse seaduse eelnõu (538SE): ekspertarvamus. Külastatud aadressil http://www.riigikogu.ee/doc.php?55263.

Riigikogu (2012). Avaliku teenistuse seadus. Riigi Teataja I, 06.07.2012, 1. Külastatud aadressil https://www.riigiteataja.ee/akt/126032013005.

Sarapuu, K. (2012). Administrative structure in times of changes. International Journal of Public Administration: The development of Estonian Ministries and Government Agencies 1990-2010, 35(12), 808-819.

doi: http://dx.doi.org/10.1080/01900692.2012.715561

Savi, R., \& Metsma, M. (2013). Public sector reform in Estonia: Views and experiences from senior executives. Retrieved from http://www.cocops.eu/wp-content/ uploads/2013/06/Estonia_WP3-Country-Report.pdf.

Sorenson, S. M. (2002). Training for the long run. Engineered Systems, 19(6), 32.

Talts, M., \& Tuisk, T. (2000). The current state of the EU related education in Estonia: The institutions and the expert. Retrieved from http://www.psych.ut.ee/esta/online/2000/full_text/2000/2/talts_tuisk.htm.

Tartu Ülikooli Euroopa kolledž (2008). Euroopa Liidu otsustusprotsessis osalevate ametnike Euroopa Liidu alase täienduskoolituse vajaduse uuring 2008-2013. P. Ehin, V. Veebel, A. Rämmer, U. Hurt, L. Luht et al. (koost.). Tartu: Tartu Ülikooli Euroopa kolledž. Külastatud aadressil

http://www.avalikteenistus.ee/public/Uuringu_anal_si_tervikraport_24_aprill.pdf.

Tõnnisson, K., \& Randma-Liiv, T. (2008). Public management reforms: Estonia. In G. Bouckaert, J. Nemec, V. Nakrosis, G. Hajnal, \& K. Tõnnisson (Eds.), Public management reforms in Central and Eastern Europe (pp. 93-118). Bratislava: NISPA.

Vabariigi Valitsus (2014). Eesti Euroopa Liidu Nõukogu eesistumise ettevalmistuste tegevuskava. Külastatud aadressil https://riigikantselei.ee/sites/default/files/contenteditors/eesistumise_ettevalmistuste_tegevuskava.pdf.

Watkins, R., \& Kaufman, R. (1996). An update on relating needs assessment and needs analysis. Performance Improvement, 35(19), 10-13.

doi: http://dx.doi.org/10.1002/pfi.4170351005 


\title{
Methodological challenges and choices when identifying EU related training needs of Estonian public service
}

\author{
Viljar Veebel ${ }^{\mathrm{a}}$, Liina Kulu ${ }^{\mathrm{b}}$, Ulrika Hurt ${ }^{\mathrm{c}}$ \\ a Estonian National Defence College, \\ Chair of Military Pedagogy and Leadership \\ ${ }^{b}$ Eesti Pank, Economics and Reaserch Department \\ ${ }^{c}$ Tallinn University of Technology, Department of Logistics
}

\section{Summary}

Increasing the knowledge and skills of the civil servants working with the European Union institutions and policies is of high importance, as their competence is a main source of country's successful representation at the EU level. The reforms of the EU determined in the Lisbon Treaty in 2009 and the EU enlargement rounds in 2007 and 2013 have increased the need for a systematic approach to the EU related competence and training in public sector even further. The need for well-targeted EU related training has even wider resonance in countries with less experience in administrative capacity building (e.g. the Central and Eastern European Countries) as well as in small EU member states. For example, in Estonia the public administration system was built in the beginning of the 1990s and central co-ordination of the system was lacking basically until mid-2000s. Accordingly, the local officialdom is characterised by the inconsistency of the public administration reform strategies and centrally co-ordinated activities, relatively limited experience of international co-operation and state officials working in their current institutions over a relatively short period of time.

Similarly, the Estonian Presidency of the European Council in 2018 is posing a significant upcoming challenge, as instead of the 500 persons currently directly related to the EU decision-making process, 1,300 civil servants will be preparing the positions, making statements, co-ordinating activities, and negotiating inside the EU as well as representing the EU in the international arena.

The current study focuses on the possible amendments into the methods used in the analysis of the EU related training needs in Estonia during the

1 Chair of Military Pedagogy and Leadership, Estonian National Defence College, Riia 12, 51013 Tartu, Estonia; viljar.veebel@gmail.com 
period 2002-2013, based on methodological shortcoming highlighted by theoretical models of the training needs assessment.

In Estonia, in total three surveys were conducted to identify the training needs in the public sector. First of them was conducted in 2002 by ESKO Training and Consultancy, the second in 2008 by the European Collage of the University of Tartu and the third in 2013 by PRAXIS. Based on the surveys conducted in 2002 and 2008, the EU related officials' training strategies respectively for the periods 2003-2005 and 2008-2012 were formulated. The survey conducted in 2014 creates the framework of the training strategy for the new period of five years, i.e. from 2013 to 2017.

All three surveys conducted in Estonia to determine the EU related training needs of local EU-officialdom were focused on the respondents' self-assessments of their current knowledge and training needs and the knowledge and training needs of their colleagues. Based on theoretical models one could assume that, as the respondents might not know what their level of knowledge is, it is very likely that they do not assess their training needs adequately either, and thus, intentionally or unintentionally, tend to over or underestimate their knowledge. At the same time, two of the surveys have not assessed the occurrence of the over and underestimation of their knowledge, skills and competencies.

The foundations as well as the results of the surveys conducted in Estonia will be analysed from the methodological point of view, and the possible amendments into the current methods used in the analysis of the EU related training needs will be suggested to improve the quality of the information received from the surveys. With regard to similar research conducted earlier (Kumpikaite \& Šiugždinienè, 2008; Meyer-Sahling, 2011; Talts \& Tuisk, 2000), the current article highlights the methodological aspects in relation to the identification of the training needs rather than describes the surveys in detail. The identification and measurement of the training needs is of key importance among other stages of training, i.e. formulation of the instructional objectives, design and implementation of training programmes, and assessment of the results. Representing the initial phase of the training cycle, the training needs assessment creates a foundation for improving the existing expertise as well as expanding the range of skills available in the workforce.

According to current research, when selecting the methods for the analysis of the EU related training needs as well as conducting the surveys, one should pay attention on the scope of the training needs' identification process (including everybody having similar understanding of the terminology), the avoidance of the expected answers on the 'dangerous' 
questions as well as ambiguous or misleading scales; and the avoidance of the Dunning-Kruger effect.

Firstly, the training needs' identification should be focused on assessing the current knowledge/skills/ training needs in particular areas. The questions in style of "how important is the topic on a broad basis”, etc. should be avoided. Also, unless a longstanding, stable and widespread meaning pertains to non-numeric grades in a specific culture, numeric values of the assessment should be preferred instead of the criteria such as 'good', 'very good'. It would likewise be crucial to include an EU related knowledge quiz or test to the official part of the survey questionnaire. Secondly, to prevent the misidentification of the training needs, the situations were training is a priority and the situations where training is not a priority, should be identified, as well as the „expected answers” should be avoided. Should the respondents as well as the persons responsible for drawing up a survey assume that the sponsor of the survey would expect that the knowledge as well as the competencies of the respondent are at the highest possible level, the respondents could be afraid to admit that they need training. For example, in the survey conducted in 2008 , the respondents clearly admitted that they have given expected answers (e.g. as extracted from the interviews "I can't discredit our ministry”, "should I as well as the majority of my colleagues admit that we need training, it might negatively impact our salaries as well as the perspectives to be promoted in the future"). Thirdly, the inadequate self-assessment of the respondents is also related to the hypothesis expressed and confirmed in the academic literature that, unless special attention is dedicated to avoid the problem, it is likely that some of the respondents do not assess their training needs adequately (called as "the Dunning-Kruger effect"). Also the results of the survey conducted in Estonia in 2008 proved that those who had less experience and were on lower positions, tended to assess themselves as knowing more than their colleagues; whereas those who had been attending more than five EU related trainings in the past twelve months claimed they needed training in most of the topics. At the same time, they succeeded in the test.

This leads us to a situation where the well-targeted strategy to overcome the lack of knowledge/skills/competencies will not be produced. Thus, selfassessment should be combined with a variety of other instruments and techniques. Therefore, as perhaps the most easily applicable option, the authors of the present article suggest to include an EU related knowledge quiz to the official part of the survey questionnaire in order to minimise the risks of over and underestimation of the knowledge and skills. 
To conclude, relying only on a single method may provide an inaccurate picture of the actual training needs in the public sector. Various levels, methods and approaches definitely contribute to the availability of comprehensive information on the actual and necessary levels of knowledge, skills and competencies among individuals. Although it would likewise be crucial to include an EU related knowledge examination to the official part of the survey questionnaire, it should consist of two parts: a) the subjective self-assessment of the respondents' level of knowledge and, b) multiplechoice questions designed to match the topics under observation in the first part of the survey. Interviews with key officials would be indicative as well, as they would allow to study the challenges and to contextualise the current situation in a country's representation and standing in the affairs of the EU.

Keywords: training, public sector, methodology, Dunning-Kruger effect 